\title{
Organizational and technological computer- aided process of real estate management
}

\author{
Lidiya Girya*, Ekaterina Zorenko, Nikita Ulianov, Dmitriy Egorov, and Aleksey \\ Nechepurenko
}

Urban construction and planning, Don State Technical University, 1, Gagarin sq., Rostov-on-Don, 344010, Russia

\begin{abstract}
The relevance of the article consists in the most frequent use of computer-aided information systems in all human sectors, including building management. These measures implementation may entail more efficient resource use and make citizens lives easier and better. The study seeks to develop a model for computer-aided project managing residential complexes and business centers based on digital technologies. For this reason, the following tasks were completed: we studied the theoretical issues of computeraided real estate management; defined the product requirements from the perspective management company; analyzed the usefulness of introducing a product for a management company; evaluated the economic efficiency. We have identified solutions that help save and optimize the use of resources. Under this study we identified the solutions enforcing careful and optimized use of resources.
\end{abstract}

\section{Introduction}

Nowadays the life of a modern person can hardly be imagined without "smart devices".

In the Russian Federation, the active introduction of broadband Internet began in 2008. On May 9, 2017, the Russian Federation adopted and developed a strategy for the development of the digital economy in order to create favorable conditions for the development of digital economy institutions and to ensure the rapid growth of the national economy by changing the structure and policy of managing national economic assets [1]. Smart digital technologies are changing the world and creating unprecedented opportunities for humans. The relevance lies in the significant application of information systems automation in all sectors of human life, including residential building management. The processes of informatization and digitalization in Russia are complicated and slow [2]. Extremely small share of housing and communal services enterprises digitizes their business processes. Even in the most prosperous sub-sector of power supply, the employment of computer-aided accounting does not exceed 9\% (the assessment of PJSC «Rosseti») [3].

Real estate as an industry was one of the first in which attempts were made to computeraided management system. The first steps to use information systems in the field of real estate dated back to the 70-80s of the last century; the software that helped optimize the life

${ }^{*}$ Corresponding author: giryal@inbox.ru 
cycle and reduce the expenses of real estate ownership was called CAFM (Computer Aided Facility Management). Since then, other systems have been created in international practice: CIFM, TIFM, IWMS, and UIFM. In fact, all of them are an extended and developed CAFM; so that all software systems, somehow related to real estate management, are often called CAFM [4, 5]. The transition to computer-aided business process, to Internet technologies will create a single information space in the industry; create IT systems for informing customers and processing their data. The main goal of real estate management is to achieve the maximum effect of their use in the interests of the owner while ensuring safe operation and maintaining the consumer qualities of the object in the long term [6]. Information systems of real estate management influence the following characteristics of economic development: labor productivity, functional efficiency, quality of customer service, creation of a quality management system, management of appeals [7].

Organizations of real estate management sector face the task of processing large quantities of data, and the processes they have to deal with are often quite complex and global, the processes themselves are formal, strict compliance with regulations is required [8, 9 Therefore, the use of information systems is most in demand where a strict documentation and support of business processes are required, large amounts of data are processed and large cash flows are circulated. Hence, computer-aided management in real estate management organizations is a highly-demanded and relevant task $[10,11]$.

Computer-aided management will simplify the business processes occurring in the management of the house (the activities of the managing company), as well as provide savings in energy consumption and increase the safety and comfort of living (in an apartment/house) [12, 13]. Most of the solutions are smart homes for computer-aided private property of specific individuals. The other decisions aim to computer-aided operating and simplifying the activities of the managing company, enhancing the prestige of real estate with the developer. Computer-integrated management involving software and hardware management of housing for owners and tools for the managing company is on the 3rd place. The computer-aided real estate market in Russia is multifaceted and represented by various types of solutions. The largest segment of the market is the computer-aided management of individual living space and managing company activities. Most computeraided products focus on physical persons and managing companies. Such solutions are relatively simple and often do not involve integrated hardware and software automation.

\section{Methods of organizational and technological processes of real estate management}

The market is filled with various solutions in the field of computer-aided real estate.

The most widespread products are aimed at solving the problems of the managing company, as well as physical persons who consider a smart home as the 21 st-century housing with a new level of comfort and security. Considering a great variety of solutions, most of them have only a limited set of functions that allow you to either computerize housing or business processes related to the activities of the managing company [14]. Few solutions combine these two automation elements. Most likely, the automation market will move in this direction in the next few years.

After analyzing the ongoing business processes in managing residential complexes of the management company, we can identify several weak points that can be automated:

1. Processes of interaction between resource-supplying organizations and managing companies, such as:

- scheduling of works performance under each contract;

- accounting and monitoring of works performance by resource-supplying organizations;

- sending requests to resource-supplying organizations; 
- failure detection (leakage, water closure, etc.);

- accounting for supplied services/resources;

- report for tenants on the work of contractors.

2. Processes of interaction between tenants of apartment buildings and managing companies, that is:

- timely payment of utility services by residents;

- timely informing tenants about possible works (power outage, hot water outage, etc.);

- report for tenants on the work of contractors $[15,16]$.

We ranked the solutions by their general functionality from the narrowest to the

broadest. The ranking was carried out on the basis of 29 parameters, including the engineering and software part. The ranking by general functionality is shown in Figure 1.

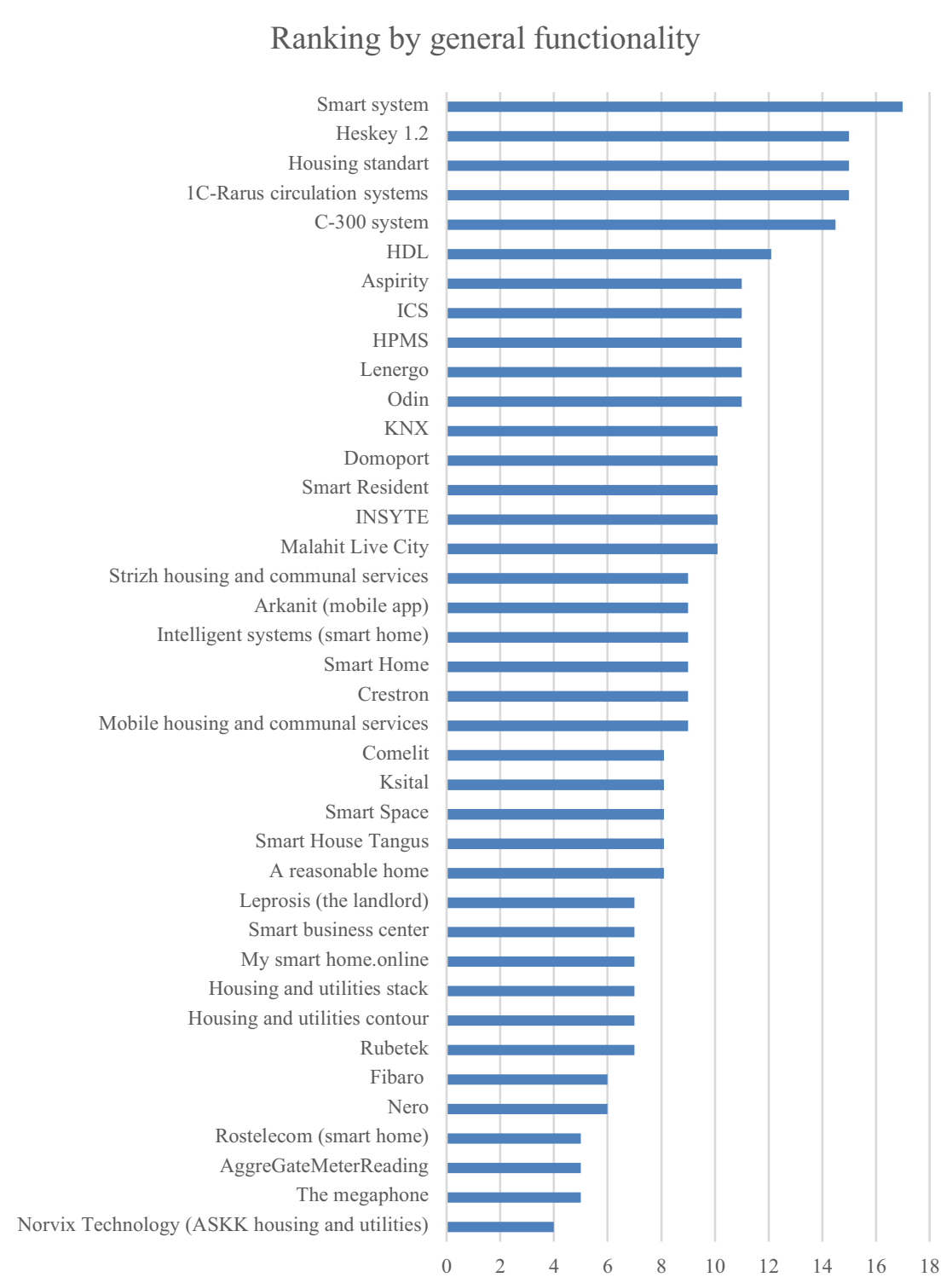

Fig. 1. Top list of products for computer-aided housing and communal services [16].

Housing and utilities stack 


\section{Results of organizational and technological processes of real estate management}

The study was based on a system for computer-aided management of residential complexes and business centers and services monetization of Home owner association (HOA)/MC HESKEY, developed by LLC «Ural Center for Security Systems». This system includes several segments of product-oriented consumers: developers; managing company and HOA; tenants and residents of business center. Different segments of consumers have different goals. You have also selected bonuses that a group can receive from implementing this solution (Table 1).

Table 1. The benefit of each segment when implementing the system.

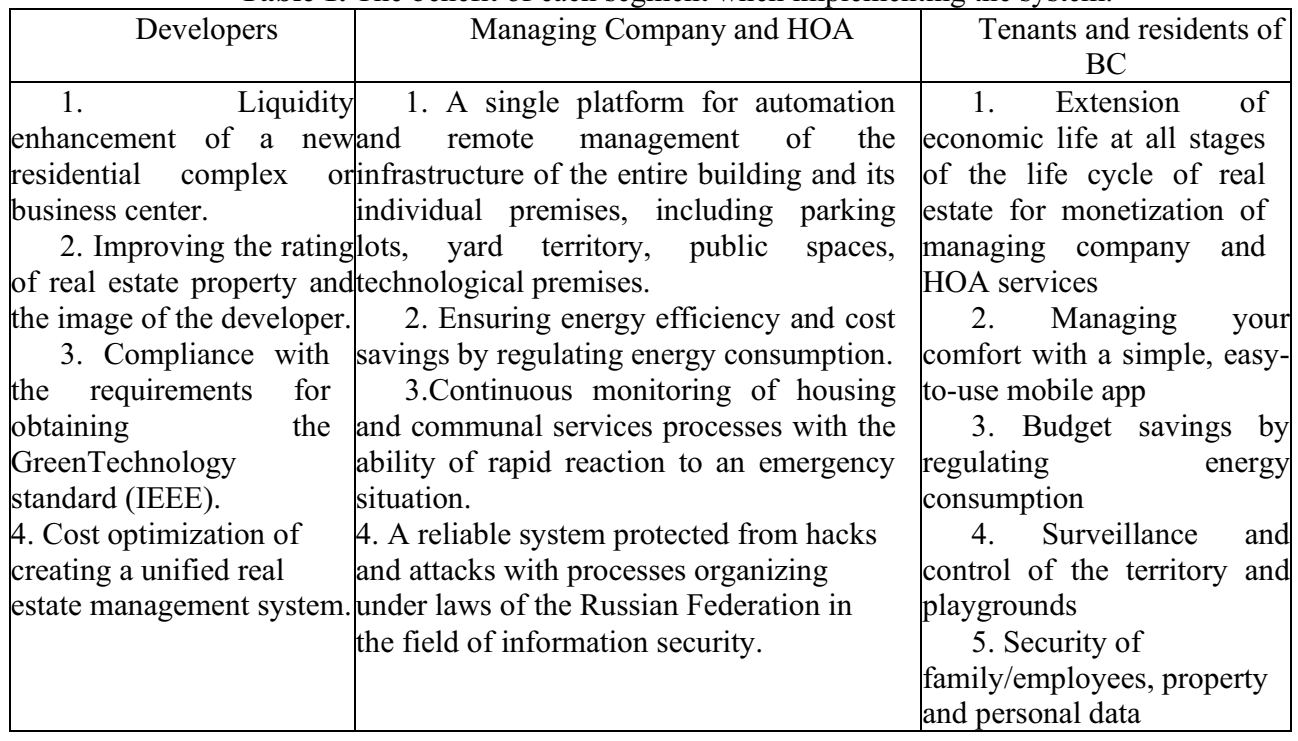

Table 2 summarizes in more detail the processes to be implemented in this system

Table 2. List of computer-aided processes by the HESKEY21 system.

\begin{tabular}{|l|l|}
\hline \multicolumn{1}{|c|}{ Functions } & \multicolumn{1}{c|}{ Details } \\
\hline Activities of & 1. News/Polling/Voting. \\
& 2. Service requests. \\
& 3. Automated collection of meter readings. \\
4. History of accruals and payments for housing and communal services. & 5. Payment of LCD online or deferred payment at the end of the month. \\
& 6. Registration of guest passes. \\
& 7. Conducting a general meeting in the system. \\
8. Service store (additional services from the managing company and outside \\
organizations). \\
9. Integration with the 1C accounting system: Accounting in the managing \\
companies of housing and communal services, HOA and housing associations or \\
the development of adapters for other systems. \\
10. Preparation of data for the GIS of housing and communal services. \\
11. Mobile application for homemaster. \\
12. Concierge service.
\end{tabular}


Table 2, continued

\begin{tabular}{|c|c|}
\hline Functions & Details \\
\hline $\begin{array}{l}\text { Personal account } \\
\text { of a resident }\end{array}$ & $\begin{array}{l}\text { 1. Access to video archive and video online from authorized video cameras. } \\
\text { 2. Information on the security breach /" fire "signal. Possibility of forced } \\
\text { release of "alarm" signal. } \\
\text { 3. Information on the temperature at the real estate unit. } \\
\text { 4. Information on the leakage at the real estate unit. Possibility of forced } \\
\text { signal release. } \\
\text { 5. Remote valves control of cold-water supply (CWS), hot-water supply } \\
\text { (HWS), heat supply. } \\
\text { 6. Informing about current resource consumption, viewing history, possibility } \\
\text { of payment. } \\
\text { 7. Managing service requests. } \\
\text { 8. Parking space management. } \\
\text { 9. Management and access control (to premises and parking lots). } \\
\text { 10. Receiving news about the complex, participating in general meetings by } \\
\text { voting. }\end{array}$ \\
\hline $\begin{array}{lr}\text { Access } & \text { control } \\
\text { and management }\end{array}$ & $\begin{array}{l}\text { 1. Performance of design works, configuration and implementation of } \\
\text { management system and access control. } \\
\text { 2. Monitoring of a real estate unit online using information from the sensors } \\
\text { of opening/impact/movement and others. } \\
\text { 3. Video door phone in the mobile application. } \\
\text { 4. Installation of end subscriber devices of door intercommunication systems } \\
\text { with audio/video panel. } \\
\text { 5. Integration of a intercom subscriber unit with a hybrid call panel (with } \\
\text { coordinate matrix or IP intercoms) at the entrance to the house section/elevator } \\
\text { hall. } \\
\text { 6. Access control at access points and for vehicles (auto barriers, gates or } \\
\text { other barriers) using: RFID cards and tags, NFC or BLE; } \\
\text { 7. Recognition of the state plate number of a vehicle from the white list and } \\
\text { by a call from a phone from the "white" list; } \\
\text { 8. The possibility of integrating the ACS system with elevator equipment. } \\
\text { 9. Security service (integration with applications of public or private security } \\
\text { companies). }\end{array}$ \\
\hline $\begin{array}{l}\text { Monitoring, } \\
\text { management and } \\
\text { dispatching of } \\
\text { engineering } \\
\text { equipment of a } \\
\text { residential } \\
\text { complex }\end{array}$ & $\begin{array}{l}\text { 1. Performance of design works, configuration and implementation of } \\
\text { computer-aided systems and dispatching of engineering equipment of the real } \\
\text { estate unit. } \\
\text { 2. Systems dispatching: } \\
\text { - power supply, considering the newly installed transforming substation (TS) } \\
\text { and DPS; } \\
\text { - elevator equipment; } \\
\text { - fire alarm system and smoke ventilation; } \\
\text { - CWS input unit, sewage pumping station equipment, water disposal. } \\
\text { 3. Use of industrial SCADA software. }\end{array}$ \\
\hline $\begin{array}{l}\text { Engineering } \\
\text { equipment } \\
\text { residential } \\
\text { complex } \\
\text { facilities }\end{array}$ & $\begin{array}{l}\text { The possibility of installation at each facility: } \\
\text { 1. CWS and HWS leakage sensors. } \\
\text { 2. Controlled drives for CWS, HWS, heating pipes (supply and return). } \\
\text { 3. Electrical group control subsystems. } \\
\text { 4. Various sensors: } \\
\text { - movement sensors (near the entrance door and on the windows) with } \\
\text { protection against false alarms from pets in order to inform the tenant about the } \\
\text { breach, using a mobile application; } \\
\text { - door opening sensor with signal output to residential complex dispatcher } \\
\text { level; } \\
\text { - temperature sensor, etc. }\end{array}$ \\
\hline
\end{tabular}


Table 2, continued

\begin{tabular}{|c|c|}
\hline $\begin{array}{l}\text { Television } \\
\text { security (video) }\end{array}$ & $\begin{array}{l}\text { 1. Performance of design works configuration and implementation of the } \\
\text { video security surveillance system. } \\
2 \text {. Installation of video cameras on the territory of a house/in sections of a } \\
\text { residential building/elevator premises, etc., in order to cover the territory as much } \\
\text { as possible. } \\
\text { 3. Video stream from authorized video cameras (the list is determined at the } \\
\text { design stage), as well as viewing the archive by authorized cameras. } \\
\text { 4. The ability to create a video archive of various storage depths. }\end{array}$ \\
\hline $\begin{array}{l}\text { Commercial } \\
\text { accounting of } \\
\text { energy resources }\end{array}$ & $\begin{array}{l}\text { 1. Installation of heat recorders for each facility, with a communication } \\
\text { interface. } \\
\text { 2. Installation of metering devices with pulse output for CWS/HWC for each } \\
\text { facility. } \\
\text { 3. Installation of electric meter with communication interface for each facility } \\
\text { 4. Installation of communication equipment and specialized software for } \\
\text { metering and remote readings of all metering devices } \\
\text { 5. Preparation of data for GIS of housing and communal services. }\end{array}$ \\
\hline $\begin{array}{l}\text { Car parking } \\
\text { management. }\end{array}$ & $\begin{array}{l}\text { Performance of design works, configuration and implementation of computer- } \\
\text { aided parking space management systems. }\end{array}$ \\
\hline
\end{tabular}

Using the example of an already implemented project, we will consider the stages necessary for the implementation of the project for developers.

The task of dispatching housing and communal services can be divided into several levels:

1. Lower level. Control and measuring equipment, computer-aided control devices. At this level, counters, calculators, PLCs are selected, and it is determined by which protocols the devices will transmit information.

2. Communications. Selection of technologies and tools for organizing the primary and twin communication channels. At this level the negotiation devices (gateways) of protocols and interfaces are also defined.

3. Dispatching. Selection of the application software that collects and processes the data.

4. Integration. Provision of communication with other subsystems and upper level systems $[17,18]$.

In general, the integrator can choose any solution to create such a system. However, within the framework of the GIS of housing and communal services, additional requirements appear that determine the approach to dispatching. For example, paragraph 14 of the process requirements of the GIS of housing and communal services determines that the system should contain mechanisms for possible expansion of functionality $[19,20]$.

Many facilities already have well-organized automation. And integrators are tasked with ensuring interaction with the GIS of housing and communal services, while the existing scheme should not disrupt its operation [21].

Given the above, the obvious problems in creating a unified dispatching system for its implementation within the framework of the GIS of housing and communal services emerged:

- collection of information on various protocols (depends on the already installed metering equipment at the facility);

- selection of the primary communication channel (Ethernet, Wi-Fi, GPRS, radio channel, etc.);

- coordination of equipment interfaces with main communication channels;

- creation of twin communication channels; 
- organization of a new information stream without disturbing the previous scheme of work;

- logging of service information for further resolution of problem situations;

- online monitoring of the state of automation devices;

- rapid detection and resolution of problem situations;

- rapid expansion of functionality in the future;

- a flexible software platform that provides information collection over any possible protocol, configurable logic, etc. [22, 23].

\section{Discussion}

At the moment, LLC «Ural Center for Security Systems» has already implemented a solution for computer-aided management processes of residential complexes and business centers and monetizing HOA /MC services on the example of the "Clever Park" residential complex with the help of the HESKEY solution. In this case, this project is considered regarding interaction with developers. When implementing functions aimed at managing companies, it is necessary to consider the economic efficiency obtained when implementing the proposed solution.

The economic justification of the project of computer-aided management processes of residential complexes and business centers consists of understanding, determining and measuring how economically useful the implementation of information technology in the business process of the company can be. At the same time, economic efficiency is the monetary equivalent of how much the company's income or expenses have increased as a result of investing in this technology. The commercial performance of the project reflects the financial results of the implementation of the information system.

In this project, for the purpose of economic benefit, we consider managing companies that manage 10 or more apartment buildings. Calculations are made for 1 apartment building. After performing the calculation, we can say that the implementation of the system for managing companies is cost-effective, but after a long period of time. In this regard, it is possible to consider reducing the functions and reducing to the minimum required product, which will entail a reduction in investment costs at the stage of purchasing equipment, which is the main expense item in our case.

\section{Conclusions}

Thus, having studied the topic of organizational and technological computer-aided processes of real estate management using digital technologies, we can conclude:

1. The automation market in Russia is studied, its overview is given, considering the segments of possible consumers, and the hardware solutions currently implemented are considered.

2. Systematized methods of organizational and technological processes of real estate management, which allow you to strictly organize and maintain business processes that process large amounts of information and large cash flows.

3. We studied "Smart housing" in the context of the "Intelligent home" and "Smart city" systems which allows you to make a more efficient management of urban resources, and the life of citizens more comfortable.

4. The theoretical issues of computer-aided management of real estate are studied. On the basis of these ones the product requirements for managing companies are developed.

5. The economical efficiency of implementing a digital system for managing companies was evaluated. The results showed that the implementation of the system is cost-efficient only after a long period of time. 


\section{References}

1. Decree of the President of the Russian Federation of May 92017 No. 203 "On the Strategy for the Development of the Information Society in the Russian Federation for 2017 - 2030";

2. Digital housing and communal services: is it easy to implement the President's plans? [Website] - Available at: http://www.iksmedia.ru/blogs/post/5398071-CzifrovoeZHKX-legko-li-realizovat.html (accessed 10.02.2021);

3. The official website of PJSC «Rosseti». [Website] - Available at: http://www.rosseti.ru (accessed 10.02.2021);

4. V. A. Egunov, A. G. Meleinov. Platform-independent management system "Smart Home," J. IZVESTIA Volga State Technical University, Volgograd, 27 p., (2017);

5. A. Sajja, D. Kharde, C. A. Pandey. Survey on efficient way to Live: Smart Home - It's an Internet of Things. ISAR - International Journal of Electronics and Communication Ethics: Textbook - 26 p., (2016);

6. F. Gray Cliford, Eric W. Larson. Project Management: Practical Guide, Moscow, "Business and Service" Publ., 20 p., (2017);

7. D.M. Zhukov. Economy and organization of housing and communal services of the city, Moscow, VLADOS-PRESS Publ., 96 p., (2016);

8. Building Automation and Security [Website] - Available at: http://knxkrasnodar.ru/oborudovanie/gira?id=116\&tmpl=component2 (accessed 10.02.2021);

9. Dispatching of housing and communal services facilities [Website] - Available at: http://cons-systems.ru/dispetcherizatciya-obektov-zhkkh (accessed 10.02.2021);

10. I.Yu. Zilberova, K.S. Petrov, Al Fatla Abdullah Neama Mohsen. Features of the planning system for repair and construction production as a part of the urban programs' implementation // IOP Conf. Series: Materials Science and Engineering 913042020 , doi:10.1088/1757-899X/913/4/042020 (2020);

11. I.Yu. Zilberova, K.S. Petrov, Al Fatla Abdullah Neama Mohsen. The influence of the technological and organizational factors on the construction process // IOP Conf. Series: Materials Science and Engineering 913 042019, doi:10.1088/1757-899X/913/4/042019 (2020);

12. V. Arkhipov, Systems for a smart building, "StroyMarket", 45, Moscow, 182 p., (2015);

13. The concept of "Smart City": fundamental principles, description, composition, examples [Website] - Available at: http://fb.ru/article/399297/kontseptsiya-umnyiygorod-osnovnyie-polojeniyaopisanie-ustroystvo-primeryi (accessed 10.02.2021);

14. Wellsoft. Overview of the enterprise automation market: solutions for construction and managing companies in the housing and communal services sector, Habr., 13 p., (2018);

15. IBC Solutions | Building and Industry Automation Solutions [Website] - Available at: http://www.ibcsol.ru/aboutcompany/ (accessed 10.02.2021);

16. S.G. Sheina, N.P. Umnyakova, P.V. Fedyaeva, E.N. Minenko. The best European experience of introducing energy-saving technologies in the housing stock of the Russian Federation/Housing construction, 6, pp. 29-34. Available at: https://doi.org/10.31659/0044-4472-2020-6-29-34, (2020);

17. S.G. Sheina, L.V. Girya, E.V. Vinogradova, A. Sobolevskiy. Methodology for a comprehensive analysis of the construction projects' accidents causes at various stages of their life cycle IOP Conference Series: Materials Science and Engineering. -Vol. 913, Is. 4. - Article 042032. - (International Scientific Conference "Construction and 
Architecture: Theory and Practice of Innovative Development" (CATPID -2020) - Part 1, 26-30 September 2020, Nalchik, Russian Federation). - Available at: https://iopscience.iop.org/article/10.1088/1757-899X/913/4/042032, (2020);

18. S. Sheina, N. Tsopa, Formation the Construction Cost for Residential Buildings at the Design Stages // International Scientific Conference Energy Management of Municipal Facilities and Sustainable Energy Technologies EMMFT pp. 224-235 - Available at: https://doi.org/10.1007/978-3-030-19868-8_23, (2018);

19. Industry Trends. Building the intelligent business platforms of tomorrow Industry Trends [Website] - Available at: https://atos.net/content/mini-sites/look-out2020/assets/ (accessed 10.02.2021);

20. I. Zilberova, K. Petrov, M. Artsishevsky. Actual Problems of Management Quality Control of a Construction Company // IOP Conference Series: Materials Science and Engineering, Volume 753, Chapter 3. 042020, doi: 10.1088/1757-899X/753/4/042020, (2020);

21. Martynov L. M., Suzdaltsev S. I. Vector of management development in competitive conditions of the information and communication business environment, Modern scientific thought J., 29, pp.112-119 (2018);

22. Methodical manual for designing architectural and planning solutions of multifunctional buildings and complexes, Moscow, pp. 27-36, 2019;

23. Amager Bakke: The Latest Architecture and News. Available at: https://www.archdaily.com/tag/amager-bakke (accessed 10.02.2021). 